Editorial

\title{
Acknowledgment to Reviewers of Oceans in 2021
}

\section{Oceans Editorial Office}

Citation: Oceans Editorial Office.

Acknowledgment to Reviewers of

Oceans in 2021. Oceans 2022, 3, 46-47.

https://doi.org/10.3390/oceans3010004

Published: 26 January 2022

Publisher's Note: MDPI stays neutral with regard to jurisdictional claims in published maps and institutional affiliations.

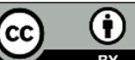

Copyright: (c) 2022 by the author. Licensee MDPI, Basel, Switzerland. This article is an open access article distributed under the terms and conditions of the Creative Commons Attribution (CC BY) license (https://creativecommons.org/license s/by/4.0/).
MDPI AG, St. Alban-Anlage 66, 4052 Basel, Switzerland

Rigorous peer-reviews are the basis of high-quality academic publishing. Thanks to the great efforts of our reviewers, Oceans was able to maintain its standards for the high quality of its published papers. Thanks to the contribution of our reviewers, in 2021, the median time to first decision was 36 days. The editors would like to extend their gratitude and recognition to the following reviewers for their precious time and dedication, regardless of whether the papers they reviewed were finally published:

Adolf Stips
Alan Cottingham
Alexander J. Werth
Alfonso Aguilar-Perera
Alfredo Aretxabaleta
Alfredo Izquierdo
Ana Lígia Primo
Ana Moura
Anderson Mayfield
Andrea Peirano
Andrea Storto
Ann M. Zoidis
Antonio Tovar Sánchez
Atsuko Fukunaga
Augusto Pérez-Alberti
B. Buongiorno Nardelli
Bernard Seret
Bernardo Duarte
Bernd Würsig
Bernhard Diekmann
Callum R. Firth
Carlos Alberto Garcia Do Vale
Caroline E Dubé
Charles Sheppard
Chen-Tung Arthur Chen
Chiara Portesi
Christopher J. Hintz
Cindy Bruyere
Claire Reymond
Cláudia Moreira
Cristian Vasar
Daniel R. Chavas
Dara Orbach
Dariusz Kucharczyk
Eleanor Watson


Lei Ren

Luca Fallati

Luis Somoza

Manuel Vargas-Yáñez

Maria Lepore

Mark Jury

Mark R. Terwilliger

Martin Le Tissier

Masaki Satoh

Masato Sugi

Matthew D. Eastin

Matthew Jones

Melita Samoilys

Michael J Risk

Michele Giani

Mitchell T. Zischke

Monika Birylo

Morales Nin Beatriz

Nadine Schubert

Narumi Takahashi

Natalie E. Wildermann

Nicola Browne

Nina Lončar

Panagiotis Agrafiotis

Paolo Montagna

Paolo Paliaga

Papaconstantinou Constantinos
Pedro J.M. Costa

Peter Davies

Peter Etnoyer

Rafael Bermudez

Ronald Osinga

Sarah Metcalfe

Scott Elliott

Senay Horozal

Shawna Foo

Shinichiro Maruyama

Simone Pietro Canese

Sophie Dennison-Gibby

Steve Archer

Teresa Serra

Terje Van Der Meeren

Tim Gordon

Tim Langlois

Tony Miskiewicz

Trika Gerard

Vasiliki Kousteni

Vinko Bandelj

Wataru Yanase

Wei Zhang

Wytze Lenstra

Yu Huang

Yuh-Lang Lin

Zinaida Osipova 